\title{
PERAN KETUA KELOMPOK TANI DALAM ADOPSI TEKNOLOGI BUDIDAYA BAWANG MERAH DI LAHAN PASIR PANTAI KECAMATAN SANDEN KABUPATEN BANTUL
}

\author{
The Role Of Chairman Of Farmer Groups In Red Onion Cultivation \\ Technology Adoption In The Sandy Beach Land Of Sanden Subdistrict Of \\ Bantul District \\ ${ }^{1}$ Eka Adi Satria Putra, ${ }^{2}$ Roso Witjaksono, ${ }^{2}$ Harsoyo \\ ${ }^{1}$ Bank BCA \\ ${ }^{2}$ Departemen Sosial Ekonomi Pertanian, Fakultas Pertanian, Universitas Gadjah Mada \\ Jalan Flora, Bulaksumur, Yogyakarta 55281 \\ satriaputra720@yahoo.co.id
}

Diterima tanggal : 4 Oktober 2016 ; Disetujui tanggal : 6 November 2016

\begin{abstract}
The research was conducted in the District Sanden Bantul and has a goal to determine: (1) the degree of the role of chairman of farmer groups in technology adoption onion cultivation in the land of sand beach, (2) the factors which affect the role of chairman of farmer groups, and (3) the influence of the role of chair of farmer groups and other factors to adoption of red onion cultivation technology in coastal sandy farming land. The basic method used in this research is descriptive analytical with survey technique. The sample villages were selected purposively, that were Srigading Village and Gadingharjo Village. Data was analyzed by frequency distribution tables and multiple linear regression analysis. The results showed that the role of chairman of farmer groups in adoption of red onion cultivation technology in the hight category. The age, education, motivation, and field extension worker role of farmers influence significantly and positively to role of chairman of farmer groups in adoption of red onion cultivation technology. Factors that influence positively the adoption of red onion cultivation technology in the sandy land are the field extension worker role and the role of chairman of the farmer groups. The age, motivation, and education of farmer, has no effect onion cultivation technology adoption in the sandy beach land.
\end{abstract}

Keywords: Group chairma, red onion, Role, , sandy land, technology adoption

\section{INTISARI}

Penelitian ini dilakukan di Kecamatan Sanden Kabupaten Bantul. Tujuannya yaitu mengetahui: (1) peran ketua kelompok tani dalam adopsi teknologi budidaya bawang merah di lahan pasir pantai, (2) faktor-faktor yang mempengaruhi peran ketua kelompok tani, dan (3) pengaruh peran ketua kelompok tani dan faktor-faktor lain tehadap adopsi teknologi budidaya bawang merah di lahan pasir pantai. Metode dasar dalam penelitian ini adalah metode deskriptif analitis dengan teknik survei. Sampel desa dipilih secara purposive, yaitu Desa Srigading dan Desa Gadingsari. Data dianalisis dengan tabel distribusi frekuensi dan analisis regresi linier berganda. Hasil penelitian menunjukkan peran ketua kelompok tani dalam adopsi teknologi budidaya bawang merah dalam kategori tinggi. Faktor umur, pendidikan, motivasi, dan peran PPL berpengaruh nyata dan berpengaruh positif terhadap peran ketua kelompok dalam adopsi teknologi budidaya bawang merah. Faktor yang 
berpengaruh terhadap adopsi teknologi budidaya bawang merah adalah peran penyuluh dan peran ketua kelompok tani. Faktor umur, pendidikan, dan motivasi tidak berpengaruh terhadap adopsi teknologi budidaya bawang merah di lahan pasir pantai.

Kata kunci: peran, ketua kelompok, adopsi teknologi, bawang merah, lahan pasir.

\section{PENDAHULUAN}

Indonesia merupakan negara agaris yang sebagian besar penduduknya berprofesi sebagai petani. Pertanian di negara Indonesia tidak akan berkembang tanpa adanya kebijakan yang berorientasi pada pembangunan pertanian secara menyeluruh. Salah satu aspek pembangunan pertanian yang sangat penting adalah adanya inovasi baru atau ide-ide baru. Keberadaan informasi-informasi pertanian tentang teknologi baru, informasi pasar, dan kebijakan-kebijakan pertanian mampu membantu memperlancar proses pembangunan pertanian. Hal tersebut dikarenakan informasi sebagai syarat terjadinya suatu perubahan yang mengarah pada kemajuan, seperti yang dikatakan Lion Berger and Gwin cit. Anggia (2013), bahwa pembaharuan teknologi pertanian memerlukan informasi khusus yang dapat mengubah pengetahuan konvensional menuju pengetahuan modern yang lebih baik.

Saat ini informasi teknologi pertanian tidak hanya difokuskan pada tanaman pangan, namun juga pada tanaman hortikultura. Bawang merah termasuk ke dalam komoditas hortikultura. Tanaman bawang merah mempunyai prospek yang cukup baik untuk meningkatkan pendapatan petani dan mendorong perkembangan agribisnis di Daerah Istimewa Yogyakarta, sehingga adanya informasi teknologi dalam budidaya tanaman bawang merah dianggap mampu mendukung kemajuan usahatani bawang merah di DIY. Daerah sentra tanaman bawang merah di Daerah Istimewa Yogyakarta terdapat di Kecamatan Sanden, Kecamatan Kretek, dan Kecamatan Srandakan, Kabupaten Bantul yang merupakan daerah sentra produksi bawang merah lahan pasir pantai. Menurut Suradal (2009), lahan pasir pantai selatan Daerah Istimewa Yogyakarta yang membentang kurang lebih $110 \mathrm{Km}$ mulai dari wilayah Kabupaten Kulon Progo, Bantul, dan Gunung Kidul merupakan lahan marginal yang memiliki faktor pembatas untuk usaha pertanian. Faktor pembatas yang dimaksud adalah: struktur tanah lepas atau pasir, kandungan bahan organik rendah, kemampuan menyimpan hara dan air rendah, dan salinitas atau kandungan garam yang cukup tinggi.

Usaha untuk meningkatkan produktivitas di lahan marginal dapat dilakukan dengan memperkenalkan suatu teknologi baru yang berspesifik lokal. Teknologi baru tersebut bisa dihasilkan dari 
teknologi lokal setempat maupun teknologi yang dihasilkan oleh lembaga penelitian. Teknologi baru tentang budidaya bawang merah perlu disebarluaskan kepada petani. Proses penyebarluaskan informasi teknologi baru dapat dilakukan dengan metode penyuluhan. Proses penyebaran informasi melalui penyuluhan ini bisa disampaikan oleh penyuluh maupun ketua kelompok tani. Melalui metode penyuluhan ini diharapkan proses transfer informasi kepada petani dapat berjalan dengan baik sehingga dapat merubah pengetahuan, sikap, dan keterampilan petani dalam budidaya bawang merah. Hal ini diperkuat dengan pernyataan Mardikanto (2009), penyuluhan adalah sebagai proses penyebarluasan informasi tentang ilmu pengetahuan, teknologi, dan seni yang dihasilkan oleh perguruan tinggi ke dalam praktek atau kegiatan praktis. Selain itu peran aktif seorang petani dalam mencari informasi dan kemampuan mengadopsi informasi teknologi baru sangat mempengaruhi keberhasilan dalam proses penyebaran informasi.

Penyuluhan pertanian mempunyai peran untuk membantu petani agar dapat menolong dirinya untuk mengatasi permasalahan yang dihadapinya secara baik dan memuaskan sehingga meningkat derajat kehidupannya. Dengan demikian nilai penting yang dianut dalam penyuluhan adalah pemberdayaan sehingga terbentuk kemandirian petani ( Sadono, 2008).
Keberhasilan penyebaran informasi teknologi baru kepada petani tidak terlepas atas peran kelompok. Dalam kehidupan masyarakat petani, biasanya petani membentuk suatu kelompok yang dinamakan dengan kelompok tani dalam membantu menjalankan usahataninya. Kelompok tani biasanya terdiri dari petanipetani yang memiliki aktivitas yang sama di bidang pertanian dan saling bekerjasama untuk meningkatkan produktivitas usahatani dan kesejahteraan anggota. Dalam kelompok tani biasanya terdiri dari anggota yang memiliki starata sosial yang berbedabeda, namun mereka menyadari adanya hubungan yang erat diantara mereka untuk mewujudkan tujuan yang sama memilki (Pertiwi, 2012). Menurut Wahyuni (2003) kelompok tani dibentuk berdasarkan surat keputusan dan dimaksudkan sebagai wadah komunikasi antarpetani, serta antara petani dengan kelembagaan terkait dalam proses alih teknologi. Surat keputusan tersebut dilengkapi dengan ketentuan-ketentuan atau tolak ukur untuk memonitor dan mengevaluasi kinerjanya. Kinerja tersebut akan menentukan tingkat kemampuan kelompok.

Dalam mewujudkan harapan yang sama suatu kelompok perlu dipimpin oleh pemimpin kelompok tani (Tampubolon, dkk 2006).

Oleh sebab itu perlu adanya pengelolaan dan manajemen yang baik agar kerjasama antar anggota tetap berjalan dengan baik dan 
kompak. Dalam mengelola dan manajemen suatu organisasi kelompok dibutuhkan pembagian peran dan tugas yang menuntut orang-orang di dalam kelompok tersebut berperan aktif sesuai dengan peran dan tugas yang telah ditentukan oleh kelompok tersebut. Salah satu peran yang sangat penting didalam kelompok tani yaitu peran ketua atau pemimpin kelompok.

Ketua atau pemimpin kelompok biasanya dipilih anggotanya berdasarkan kemampuan dan kinerja yang dimiliki. Salah satu kemampuan yang dimiliki oleh ketua kelompok yaitu kemampuan dalam berperan aktif untuk mencari dan menyerap suatu teknologi baru serta mampu menyebarluaskan dan menggerakkan anggotanya untuk menerapkan teknologi baru tersebut. Sehingga peran ketua kelompok disini selain sebagai organisator dan komunikator tetapi juga sebagai fasilitator petani dalam meningkatkan pengetahuan maupun keterampilan dalam kegiatan usaha tani anggotanya.

Berdasarkan uraian di atas, sejauh mana peran ketua kelompok tani dalam adopsi teknologi budidaya bawang merah di lahan pasir pantai Kecamatan Sanden, Kabupaten Bantul, Yogyakarta dan faktor-faktor yang mempengaruhi adopsi teknologi budidaya bawang merah terhadap adopsi teknologi budidaya bawang merah menarik untuk dikaji.

Penelitian yang dilakukan sebelumnya menunjukkan bahwa faktor- faktor yang mempengaruhi kecepatan adopsi yaitu sifat inovasi, sifat calon pengguna dan saluran komunikasi (Harianta, Y.W., 2011), namun penelitian yang dilakukan oleh Rangkuti (2009), peran ketua kelompok tani mendominasi struktur jaringan komunikasi petani dalam proses adopsi inovasi.

\section{METODE PENELITIAN}

Metode dasar yang digunakan dalam penelitian ini adalah deskriptif. Penelitian deskriptif tertuju pada pemecahan masalah yang ada pada masa sekarang. Metode deskriptif adalah dapat diartikan sebagai prosedur pemecahan masalah yang diselidiki, dengan menggambarkan atau melukiskan keadaan objek penelitian pada saat sekarang, berdasarkan fakta-fakta yang tampak atau sebagaimana adanya. Metode deskriptif memusatkan perhatiannya pada penemuan fakta-fakta (fact finding) sebagaimana keadaan sebenarnya (Nawawi dan Mimi, 1994).

Dalam penelitian ini teknik pelaksanaannya dengan menggunakan metode survei. Semua informasi dikumpulkan dari responden dengan menggunakan kuesioner. Pengertian survei pada umumnya dibatasi oleh pengertian survei sampel yang mana informasi dikumpulkan dari sebagian populasi untuk mewakili seluruh populasi (Singarimbun dan Effendi, 1982). Penelitian ini dilakukan di Kecamatan Sanden, Kabupaten Bantul, Yogyakarta. Kecamatan 
Sanden merupakan kecamatan yang paling potensial untuk kegiatan budidaya bawang merah di lahan pasir pantai. Sampel yang diambil meliputi sampel desa, sampel kelompok tani, dan sampel petani. Sampel desa di Kecamatan Sanden yang dipilih adalah Desa Srigading dan Desa Gadingsari dengan metode purposive sampling. Kedua desa tersebut mempunyai kelompok tani dan semua anggotanya merupakan petani bawang merah di lahan pasir pantai sedangkan umtuk kelompok tani yang dipilih adalah kelompok Tani Manunggal dan Kelompok Tani Phitisari. Kedua kelompok tani ini dipilih dengan metode purposive sampling karena semua anggotanya merupakan petani lahan pasir dan setiap musimnya melakukan kegiatan budidaya bawang merah. Petani yang menjadi sampel diambil secara simple random sampling sejumlah 30 petani dari masing-masing sampel kelompok tani. Jumlah keseluruhan sampel petani yang diambil dalam penelitian ini adalah 60 orang.

Penyimpulan hipotesis apakah diterima atau ditolak dilakukan melalui analisis terhadap data yang diperoleh. Untuk menjawab tujuan penelitian maka dikemukakan 3 hipotesis sebagai berikut:

a) Pengujian hipotesis pertama untuk mengetahui peranan Ketua kelompok dalam adopsi teknologi budidaya tanaman bawang merah di lahan pasir Kecamatan Sanden Kabupaten Bantul digunakan uji proporsi, pengujian tersebut sebagai berikut :
Pengujian hipotesis

Ho : $\mathrm{P} \leq 50 \%$

$\mathrm{Ha}: \mathrm{P}>50 \%$

Keterangan :

Ho : diduga kurang dari atau sama dengan $50 \%$ peran ketua kelompok dalam adopsi teknologi budidaya bawang merah di lahan pasir Kabupaten Bantul dalam kategori rendah.

Ha : diduga lebih dari $50 \%$ peran ketua kelompok dalam adopsi teknologi budidaya bawang merah di lahan pasir Kabupaten Bantul dalam kategori tinggi.

Tingkat signifikansi yang digunakan pada $\alpha$ : 0,05 (5\%) dengan $n=60$ dan tatistik pengujian (Dixon and Massey, 1969) :

$$
\mathrm{Z}=\frac{\frac{\frac{x}{n}-p_{O}}{\sqrt{\frac{P a(1-P O)}{n}}}}{\sqrt{\frac{1}{n}}}
$$

$\mathrm{x}=$ jumlah petani sampel yang memiliki adopsi tinggi

$\mathrm{n}=$ jumlah keseluruhan petani yang menjadi sampel

$\mathrm{Po}=50 \%$

Kriteria pengujian:

Z hitung $\leq$ Z tabel: Ho diterima, Ha ditolak, serta

Z hitung $>$ Z tabel : Ho ditolak, Ha diterima

b) Pengujian hipotesis kedua untuk mengetahui faktor-faktor yang mempengaruhi peran ketua kelompok tani adopsi teknologi budidaya bawang merah di lahan pasir Kabupaten Bantul. 
Persamaan regresi linear berganda sebagai beikut (Sugiyono, 2014) :

$\mathrm{Y}=\mathrm{a}+\mathrm{b}_{1} \cdot \mathrm{X}_{1}+\mathrm{b}_{2} \cdot \mathrm{X}_{2}+\mathrm{b}_{3} \cdot \mathrm{X}_{3}+\mathrm{b}_{4} \cdot \mathrm{X}_{4}+\mathrm{e}$

Keterangan :

Y = adopsi teknologi budidaya bawang merah

a = nilai konstanta

$\mathrm{b}_{1}-\mathrm{b}_{4}=$ koefisien regresi

$\mathrm{X}_{1} \quad=$ umur petani

$\mathrm{X}_{2} \quad=$ tingkat pendidikan petani

$\mathrm{X}_{3}=$ motivasi petani

$\mathrm{X}_{4} \quad=$ peran penyuluh

Hipotesis yang digunakan

Ho : $\mathrm{X}_{1}=\mathrm{X}_{2}=\mathrm{X}_{3}=\mathrm{X}_{4}$

Ha: $X_{1} \neq X_{2} \neq X_{3} \neq X_{4}$

Dengan pengertian :

Ho : Diduga tidak ada pengaruh antara umur petani, pendidikan petani, motivasi petani, dan peran penyuluh dalam adopsi teknologi budidaya bawang merah di lahan pasir Kabupaten Bantul.

Ha: Diduga ada pengaruh antara umur petani, pendidikan petani, motivasi petani, dan peran penyuluh dalam adopsi teknologi budidaya bawang merah di lahan pasir Kabupaten Bantul.

Kriteria pengujian yaitu dengan menggunakan aplikasi program SPSS 16.0 for Windows dengan metode backward yang secara bertahap menghilangkan faktor-faktor yang tidak berpengaruh nyata dengan taraf signifikansi $10 \%$ $(0,01)$.

c) Pengujian hipotesis ketiga untuk mengetahui sejauh mana karakteristik petani dan peranan ketua kelompok tani dalam mempengaruhi adopsi teknologi budidaya bawang merah di lahan pasir Kabupaten Bantul.

Persamaan regresi linear berganda sebagai berikut (Sugiyono, 2014) :

$$
\begin{aligned}
Y= & a+b_{1} \cdot X_{1}+b_{2} \cdot X_{2}+b_{3} \cdot X_{3}+b_{4} \cdot X_{4} \\
& +b_{5} \cdot X_{5}+e
\end{aligned}
$$

Keterangan :

$\mathrm{Y} \quad=$ adopsi teknologi budidaya bawang merah

a = nilai konstanta

$\mathrm{b}_{1}-\mathrm{b}_{5}=$ koefisien regresi

$\mathrm{X}_{1} \quad=$ umur petani

$\mathrm{X}_{2} \quad$ = tingkat pendidikan petani

$\mathrm{X}_{3} \quad=$ motivasi petani

$\mathrm{X}_{4} \quad=$ peran penyuluh

$\mathrm{X}_{5} \quad=$ peranan ketua kelompok tani

Hipotesis yang digunakan Ho : $\mathrm{X}_{1}=\mathrm{X}_{2}=\mathrm{X}_{3}=\mathrm{X}_{4}=\mathrm{X}_{5}$ $\mathrm{Ha}: \mathrm{X}_{1} \neq \mathrm{X}_{2} \neq \mathrm{X}_{3} \neq \mathrm{X}_{4} \neq \mathrm{X}_{5}$

Dengan pengertian :

Ho : diduga tidak ada pengaruh antara umur petani, pendidikan petani, motivasi petani, peran penyuluh, 
peranan ketua kelompok sebagai motivator, peranan ketua kelompok sebagai komunikator, peranan ketua kelompok sebagai fasilitator, dan peranan ketua kelompok sebagai organisator dengan adopsi teknologi budidaya bawang merah di lahan pasir Kabupaten Bantul.

Ha : diduga ada pengaruh antara umur petani, pendidikan petani, motivasi petani, peran penyuluh, peranan ketua kelompok sebagai motivator, peranan ketua kelompok sebagai komunikator, peranan ketua kelompok sebagai fasilitator, dan peranan ketua kelompok sebagai organisator dengan adopsi teknologi budidaya bawang merah di lahan pasir Kabupaten Bantul.

Kriteria pengujian dengan menggunakan aplikasi program SPSS 16.0 for Windows dengan metode backward yang secara bertahap menghilangkan faktor-faktor yang tidak berpengaruh nyata dengan taraf signifikansi $10 \%(0,01)$.

\section{HASIL DAN PEMBAHASAN}

Peran Ketua Kelompok Tani Dalam Adopsi Teknologi Budidaya Bawang Merah Di Lahan Pasir Pantai Kecamatan Sanden Kabupaten Bantul

Ketua kelompok tani merupakan seorang pemimpin yang bertanggung jawab atas setiap kegiatan yang ada dalam kelompok tani. Ketua kelompok tani sebagai seorang pemimpin dalam kelompoknya mempunyai peran sebagai komunikator yaitu memberikan informasi-informasi bidang pertanian kepada petani. Melalui peran ketua kelompok tani inilah teknologi budidaya bawang merah diinformasikan kepada sesama anggotapetani lahan pasir pantai Kecamatan Sanden Kabupaten Bantul. Ketua kelompok tani juga mempunyai peran sebagai motivator yaitu pemberi semangat petani, sedangkan sebagai fasilitator yaitu memberikan fasilitas-fasilitas yang dibutuhkan petani dan sebagai organisator yaitu ketua kelompok dapat menggerakkan dan mengorganisir kegiatan kelompok tani agar mewujudkan keberlanjutan usaha tani tetap hidup (eksistensi) (Pribadi, 2008).Pada tabel 1 menujukkan peran ketua kelompok tani di Kecamatan Sanden.

Berdasarkan Tabel 1 dapat diketahui bahwa tingkat peran ketua kelompok tani cukup tinggi, yaitu sebesar $62,43 \%$, artinya ketua kelompok tani sudah dapat menjalankan perananya sebagai motivator, komunikator, fasilitator, dan organisator bagi anggota kelompoknya yaitu petani bawang merah di Kecamatan Sanden.

Sedangkan Tabel 2 merupakan hasil analisis menggunakan metode backward dan didapatkan satu model analisis. 
Tabel 1. Peran Ketua Kelompok Tani di Kecamatan Sanden

\begin{tabular}{lrrr}
\hline \multicolumn{1}{c}{ Indikator } & Interval Skor & Skor Rerata Capaian & Tingkat Peran (\%) \\
Motivator & $0-17$ & 12,28 & 73,28 \\
Komunikator & $0-17$ & 10,82 & 63,55 \\
Fasilitator & $0-13$ & 4,74 & 36,63 \\
Organisator & $0-21$ & 16,30 & 76,27 \\
\hline Jumlah & $0-68$ & 44,14 & 62,43 \\
\hline
\end{tabular}

Sumber: Analisis Data Primer, 2016

Tabel 2. Sebaran Petani Berdasarkan Tingkat Peran Ketua Kelompok Tani di Kecamatan Sanden

\begin{tabular}{lrr}
\hline Kategori Peran Ketua Kelompok & Jumlah (orang) & Persentase (\%) \\
\hline Rendah (0-34) & 9 & 15,00 \\
Tinggi (35-68) & 51 & 85,00 \\
\hline Jumlah & 60 & 100 \\
\hline
\end{tabular}

Sumber: Analisis Data Primer, 2016

Hipotesis pertama pada penelitian ini yaitu diduga peran ketua kelompok tani di lahan pasir pantai Kabupaten Bantul dalam kategori tinggi yaitu $85 \%$. Untuk membuktikan hipotesis pertama dilakukan uji proporsi sebagai berikut:

Signifikansi 10\%, $x=51, n=60, P o=50 \%$

$$
\begin{aligned}
Z_{\text {hit }} & =\frac{51 / 60-0,5}{\sqrt{\frac{0,5(1-0,5)}{60}}} \\
& =7,746 \\
Z_{\text {tabel }} & =-1,645
\end{aligned}
$$

maka Zhitung>Ztabel sehingga Ho ditolak dan Ha diterima. Hal ini menunjukkan bahwa peranan ketua kelompok tani dalam adopsi teknologi budidaya bawang merah di lahan pasir pantai Kabupaten Bantul dalam kategori tinggi.
Faktor-faktor yang Mempengaruhi Peranan Ketua Kelompok Tani dalam Adopsi Teknologi Budidaya Bawang Merah di Lahan Pasir Pantai

Indikator peranan ketua kelompok tani bawang merah yang diteliti mencakup peran ketua sebagai motivator, komunkator, fasilitator, dan organisator. Dalam penelitian ini diduga faktor umur, pendidikan, motivasi, dan peran penyuluh mempengaruhi peranan ketua kelompok tani.

Berdasarkan tabel 3 dapat diketahui bahwa semua variabel yang dianalisis signifikan yaitu semua variabel independen : umur, pendidikan, motivasi dan peran penyuluh. Keempat variabel tersebut berpengaruh nyata terhadap peran ketua kelompok tani karena memiliki nilai signifikansi lebih kecil dari $\alpha$ : 0,1. Selain 
itu, dari tabel diatas dapat diketahui bahwa nilai adjusted $R$ square adalah 0,129 yang berarti $12,9 \%$ variabel peran ketua kelompok dipengaruhi oleh variabel umur, pendidikan, motivasi, dan peran penyuluh.

Sedangkan $87.10 \%$ dipengaruhi oleh variabel-variabel lain di luar model.

Berdasarkan hasil analisis regresi pada Tabel 3 maka diperoleh persamaan regresi sebagai berikut:

$$
\begin{aligned}
Y= & 0,037+0,322 X_{1}+1,052 X_{2} \\
& +0,269 X_{3}+0,207 X_{4}
\end{aligned}
$$

Keterangan:

$\mathrm{Y}=$ Peran ketua kelompok tani

$\mathrm{X}_{1}=$ Umur

$\mathrm{X}_{2}=$ Pendidikan

$\mathrm{X}_{3}=$ Motivasi

$\mathrm{X}_{4}=$ Peran penyuluh

Berikut hasil uji tiap-tiap hipotesis yang mempengaruhi peran ketua kelompok tani kelompok tani:

\section{Umur Petani}

Nilai koefisien regresi umur petani yang terdapat pada Tabel 3 adalah 0,322 dengan nilai signifikansi 0,040. Dapat diketahui bahwa nilai signifikansi umur petani lebih rendah dari pada taraf signifikansi $\alpha$ : 0,1 sehingga variabel umur berpengaruh nyata terhadap peran ketua kelompok tani, yang artinya adalah semakin muda atau tua umur petani akan mempengaruhi tinggi rendahnya peranan ketua kelompok tani. Berdasarkan persamaan regresi tersebut, dapat dibuat grafik yang menggambarkan hubungan antara umur petani dengan peran ketua kelompok tani di mana terdapat asumsi bahwa variabel lainnya konstan dan dapat diketahui bahwa koefisien regresi bernilai positif (+). Pengaruh positif ini menunjukkan bahwa setiap penambahan nilai variabel umur akan menaikkan peran ketua kelompok tani.

\section{Pendidikan Petani}

Tabel 3 dapat diketahui bahwa nilai koefisien regresi pendidikan yaitu 1,052 dengan nilai signifikansi 0,062 . Nilai signifikansi lebih kecil daripada taraf signifikansi $\alpha$ : 0,1 sehingga variabel pendidikan petani berpengaruh nyata terhadap peranan ketua kelompok tani. Hal ini menunjukkan bahwa semakin tinggi pendidikan seorang petani maka semakin tinggi pula peran ketua kelompok tani. Berdasarkan persamaan regresi tersebut, dapat dibuat grafik yang menggambarkan hubungan antara pendidikan petani dengan peran ketua kelompok tani di mana terdapat asumsi bahwa variabel lainnya konstan dan dapat diketahui bahwa koefisien regresi bernilai positif $(+)$. Pengaruh positif ini menunjukkan bahwa setiap penambahan nilai variabel pendidikan akan menaikkan peran ketua kelompok tani

\section{Motivasi}

Nilai koefisien regresi motivasi pada tabel 3 yaitu 0,269 dengan nilai signifikansi 
Tabel 3. Hasil Analisis Regresi Linier Berganda Mengenai Faktor-faktor yang Mempengaruhi Peran Ketua Kelompok Tani (Model 1)

\begin{tabular}{lrrrc}
\hline \multicolumn{1}{c}{ Variabel } & Koefisien Regresi & t hitung & Signifikansi & Ket \\
\hline Umur Petani $\left(\mathrm{X}_{1}\right)$ & 0,322 & 2,099 & 0,040 & $*$ \\
Pendidikan Petani $\left(\mathrm{X}_{2}\right)$ & 1,052 & 1,903 & 0,062 & $*$ \\
Motivasi $\left(\mathrm{X}_{3}\right)$ & 0,269 & 2,095 & 0,041 & $*$ \\
Peran penyuluh $\left(\mathrm{X}_{4}\right)$ & 0,207 & 1,790 & 0,079 & $*$ \\
\hline Konstanta & 0,037 & & & \\
$\mathrm{R}$ & 0,434 & & & \\
R Square & 0,188 & & & \\
Adjusted R Square & 0,129 & & & \\
F hitung & 3,183 & & & \\
Keterangan: * signifikansi pada taraf 10\% & & & & \\
$\quad$ NS : Non Signifikan pada taraf 10\% & & &
\end{tabular}

Sumber: Analisis Data Primer, 2016

0,041. Nilai signifikansi motivasi lebih kecil daripada taraf signifikansi $\alpha$ : 0,1 sehingga motivasi petani berpengaruh nyata terhadap peranan ketua kelompok tani. Hal ini menunjukkan bahwa tinggi rendah motivasi petani berpengaruh terhadap peran ketua kelompok kelompok tani Berdasarkan persamaan regresi tersebut, dapat dibuat grafik yang menggambarkan hubungan antara motivasi petani dengan peran ketua kelompok tani di mana terdapat asumsi bahwa variabel lainnya konstan dan dapat diketahui bahwa koefisien regresi bernilai positif $(+)$. Pengaruh positif ini menunjukkan bahwa setiap penambahan nilai variabel motivasi akan menaikkan peran ketua kelompok tani

\section{Peran Penyuluh}

Berdasarkan tabel 3 dapat diketahui bahwa nilai koefisien regresi peran penyuluh adalah 0,207 dengan nilai signifikansi sebesar 0,079. Dari nilai signifikansi diatas diketahui bahwa niali signifikansi peran penyuluh lebih kecil daripada taraf signifikansi $\alpha$ : 0,1 , sehingga peran penyuluh berpengaruh nyata terhadap peran ketua kelompok tani, Hal ini menunjukkan bahwa tinggi rendahnya peran penyuluh mempengaruhi peran ketua kelompo tani.

Berdasarkan persamaan regresi tersebut, dapat dibuat grafik yang menggambarkan hubungan antara peran penyuluh dengan peran ketua kelompok tani di mana terdapat asumsi bahwa variabel lainnya konstan dan dapat diketahui bahwa koefisien regresi bernilai positif (+). Pengaruh positif ini menunjukkan bahwa setiap penambahan nilai variabel peran penyuluh akan menaikkan peran ketua kelompok tani Pengaruh Peran Ketua Kelompok Tani dan Faktor Internal serta Faktor Eksternal Petani terhadap Adopsi Teknologi Budidaya Bawang Merah di 
Tabel 4. Sebaran Petani Berdasarkan Tingkat Adopsi di Kecamatan Sanden

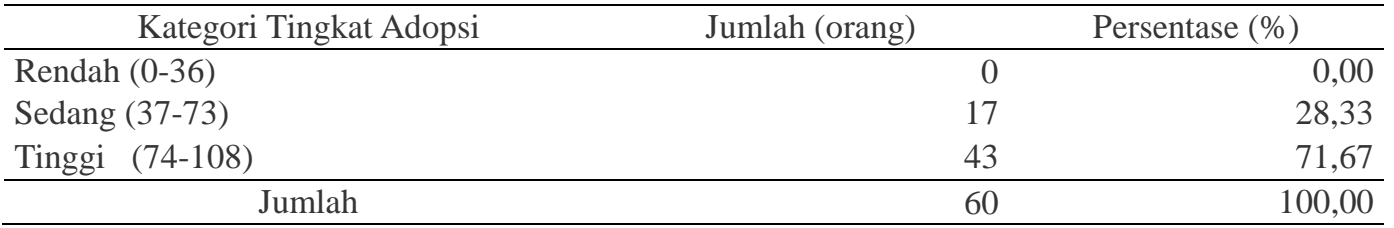

Sumber: Analisis Data Primer, 2016

Tabel 5 Hasil Analisis Regresi Linier Berganda Mengenai Faktor-faktor yang Mempengaruhi Adopsi Teknologi Budidaya Bawang Merah (Model 4)

\begin{tabular}{lrrrr}
\hline \multicolumn{1}{c}{ Variabel } & \multicolumn{1}{c}{$\begin{array}{c}\text { Koefisien } \\
\text { Regresi }\end{array}$} & t hitung & Signifikansi & Ket \\
\hline Peran Ketua Kelompok Tani $\left(\mathrm{X}_{1}\right)$ & 0,281 & 2,0764 & 0,042 & $*$ \\
Peran penyuluh $\left(\mathrm{X}_{2}\right)$ & 0,415 & 3,3172 & 0,020 & $*$ \\
\hline Konstanta & 56,166 & & \\
R & 0,507 & & \\
R Square & 0,257 & & \\
Adjusted R Square & 0,231 & & \\
F hitung & 9,869 & & \\
F table & 2,398 & & \\
\hline Keterangan & & & \\
\hline
\end{tabular}

Keterangan: * signifikansi pada taraf $10 \%$

Sumber: Analisis Data Primer, 2016

Lahan Pasir Pantai Dalam penelitian ini diduga adopsi teknologi budidaya bawang merah di lahan pasir dipengaruhi oleh peran ketua kelompok tani, faktor umur, pendidikan, luas lahan, motivasi, peran penyuluh. Untuk mengetahui sebaran petani berdasarkan tingkat adopsi dapat dilihat pada tabel 4 dibawah ini : Dari Tabel 4 dapat diketahui bahwa sebagian besar petani menilai tinggi adopsi teknologi budidaya bawang merah di lahan pasir pantai dengan persentase $71,67 \%$ dengan jumlah 43 orang. Untuk petani yang menilai sedang berjumlah 17 orang dengan persentase $28,33 \%$, sedangkan tidak ada petani yang terdapat pada kategori rendah. Selanjutnya, faktor-faktor yang diduga berpengaruh nyata terhadap adopsi teknologi budidaya bawang merah dianalisis berdasarkan data yang telah diperoleh dari lapangan. Hasil analisis linier berganda dengan metode Backward pada aplikasi SPSS untuk mengetahui faktor-faktor yang mempengaruhi peran ketua kelompok tani dapat dilihat pada tabel 5 .

Dari tabel 5 tentang hasil analisis regresi berganda pada menyatakan bahwa nilai signifikansi peran ketua kelompok tani dan peran penyuluh lebih kecil daripada taraf signifikansi $\alpha$ : 0,1 . Hal ini menunjukkan bahwa peran ketua 
kelompok tani dan peran penyuluh memiliki pengaruh nyata terhadap adopsi teknologi budidaya bawang merah. Sedangkan nilai adjusted $R$ square sebesar 0,231 menunjukkan bahwa 23,1\% variabel adopsi teknologi budidaya bawang merah dapat dijelaskan oleh variabel peran ketua kelompok tani dan peran penyuluh sedangkan $76,9 \%$ sisanya, dijelaskan oleh variabel lain di luar model tersebut.

Berdasarkan hasil analisis regresi linier berganda pada Tabel 5 maka diperoleh persamaan regresi sebagai berikut:

$$
Y=56,166+0,281 X_{1}+0,415 X_{2}
$$

Keterangan:

$\mathrm{Y}=$ Adopsi teknologi budidaya bawang merah

$\mathrm{X}_{1}=$ Peran ketua kelompok tani

$\mathrm{X}_{2}=$ Peran penyuluh

Berikut ini akan dibahas hasil uji hipotesis masing-masing faktor yang berpengaruh nyata yang merupakan hasil analisis regresi linier berganda pada Model 7:

\section{Ketua Kelompok Tani}

Berdasarkan Tabel 5 dapat diketahui bahwa nilai koefisien regresi peran ketua kelompok tani adalah 0,281 dan nilai signifikansi 0,042. Variabel peran ketua kelompok tani memiliki t hitung sebesar 2,076 lebih tinggi daripada $\mathrm{t}$ tabel 1,671 sehingga Ha diterima karena $\mathrm{t}$ hitung $>\mathrm{t}$ tabel. Hal ini berarti variabel peran ketua kelompok tani berpengaruh nyata terhadap tingkat adopsi teknologi budidaya bawang merah di lahan pasir pantai.

Berdasarkan persamaan regresi tersebut, dapat dibuat grafik yang menggambarkan hubungan antara peran ketua kelompok tani dengan adopsi teknologi di mana terdapat asumsi bahwa variabel lainnya konstan dan dapat diketahui bahwa koefisien regresi bernilai positif (+). Pengaruh positif ini menujukkan bahwa setiap penambahan variabel peran ketua kelompok tani akan meningkatkan adopsi teknologi budidaya.

\section{Peran Penyuluh}

Dari tabel 5 dapat dilihat bahwa nilai koefisien regresi peran penyuluh adalah 0,451 dan nilai signifikansi sebesar 0,020. Dari nilai signifikansi diatas diketahui bahwa niali signifikansi peran penyuluh lebih kecil daripada taraf signifikansi $\alpha$ : 0,1 . Sehingga peran penyuluh berpengaruh nyata terhadap peran ketua kelompok tani, artinya bahwa tinggi rendahnya peran penyuluh mempengaruhi peran ketua kelompok tani. Selain itu variabel umur petani mempunyai $\mathrm{t}$ hitung 3,317 dan $\mathrm{t}$ tabel sebesar 1,671. Hal ini menunjukkan bahwa Ha diterima karena thitung > $t$ tabel. Dengan demikian, variabel umur berpengaruh nyata terhadap peran ketua kelompok tani di Kecamatan Sanden, Kabupaten Bantul. 
Berdasarkan persamaan regresi tersebut, dapat dibuat grafik yang menggambarkan hubungan antara peran penyuluh dengan adopsi teknologi di mana terdapat asumsi bahwa variabel lainnya konstan dan dapat diketahui bahwa koefisien regresi bernilai positif (+). Pengaruh positif ini menunjukkan bahwa setiap penambahan nilai variabel peran penyuluh akan menaikkan adopsi teknologi budidaya bawang merah.

Menurut Amanah (2007) sebagai sebuah tindakan praktis, penyuluhan merupakan upaya-upaya yang dilakukan untuk mendorong terjadinya perubahan perilaku pada individu, kelompok, komunitas, ataupun masyarakat agar mereka tahu, mau, dan mampu menyelesaikan permasalahan yang dihadapi. Tujuan penyuluhan tidak lain adalah agar hidup dan kehidupan manusia yang berkualitas dan bermartabat.

\section{KESIMPULAN DAN SARAN}

\section{Kesimpulan}

1. Dalam penelitian ini peran ketua kelompok tani dalam adopsi teknologi budidaya bawang merah di lahan pasir pantai Kecamatan Sanden Kabupaten Bantul termasuk dalam kategori tinggi dengan persentase sebesar $85 \%$.

2. Peran ketua kelompok tani dalam adopsi teknologi budidaya bawang merah di lahan pasir Kecamaran Sanden Kabupaten Bantul yaitu sebagai motivator, komunikator, fasilitator, dan organisator. Ketua kelompok tani sering menjalankan peranannya sebagai motivator dan organisator, sedangkan sebagai komunikator hanya kadang-kadang dilakukan dan sebagai fasilitator jarang dilakukan.

3. Faktor-faktor yang berpengaruh nyata terhadap peranan ketua kelompok tani dalam adopsi teknologi budidaya bawang merah di lahan pasir pantai adalah umur, pendidikan petani, motivasi dan peran penyuluh.

a. Semakin tinggi umur petani maka semakin tinggi peran ketua kelompok tani dalam adopsi teknologi budidaya bawang merah di lahan pasir pantai.

b. Semakin tinggi pendidikan petani maka semakin tinggi peran ketua kelompok tani dalam adopsi teknologi budidaya bawang merah di lahan pasir pantai.

c. Semakin tinggi motivasi petani maka semakin tinggi peran ketua kelompok tani dalam adopsi teknologi budidaya bawang merah di lahan pasir pantai.

d. Semakin tinggi peran penyuluhn maka semakin tinggi peran ketua kelompok tani dalam adopsi teknologi budidaya bawang merah di lahan pasir pantai.

4. Sebesar $71,67 \%$ petani memiliki tingkat adopsi yang tinggi dalam budidaya bawang merah di lahan pasir pantai. 
5. Faktor- faktor yang berpengaruh nyata terhadap adopsi teknologi budidaya bawang merah di lahan pasir pantai adalah peran ketua kelompok tani dan peran penyuluh.

a. Semakin tinggi peran ketua kelompok tani maka semakin tinggi adopsi teknologi budidaya bawang merah di lahan pasir pantai.

b. Semakin tinggi peran penyuluh maka semakin tinggi adopsi teknologi budidaya bawang merah di lahan pasir pantai.

\section{Saran}

1. Peran ketua kelompok tani dapat ditingkatkan dengan cara meningkatkan motivasi ketua kelompok tani agar kinerja ketua kelompok sebagai fasilitator dan organisator berjalan dengan baik.

2. Agar motivasi ketua kelompok dapat meningkat dapat dilakukan dengan cara meningkatkan peran penyuluh untuk selalu mendampingi dan memberi dorongan moril kepada kelompok terutama ketua kelompok tani.

3. Peran penyuluh masih perlu ditingkatkan terutama dalam hal memberikan motivasi dan fasilitasi kepada petani. Aspek motivasi, terutama dalam mendorong petani untuk mengikuti kegiatan penyuluhan dan dalam mendorong meningkatkan kualitas hasil produksi.
Aspek motivasi, terutama dalam memfasilitasi penyediaan modal dan sarana produksi.

4. Tingkat adopsi teknologi budidaya bawang merah di lahan pasir pantai yang tinggi diharapkan dapat dimanfaatkan oleh penyuluh dan ketua kelompok tani untuk semakin berperan aktif dalam memberikan penyuluhan dan pengembangan teknologi baru.

\section{DAFTAR PUSTAKA}

Amanah, S. 2007. Makna Penyuluhan dan Transformasi Perilaku Manusia. Jurnal Penyuluhan 3 (1) : 63-67.

Dixon, W. J. and F. J. Massey. 1969. Introduction to Statistical Analysis McGraw Hill, Kogakusha.

Harinta, Y.W. 2011. Adopsi Inovasi Pertanian di Kalangan Petani di Kecamatan Gatak Kabupaten Sukoharjo. Jurnal Agrin 15 (2) : 164-174.

Mardikanto, T. 2009. Sistem Penyuluhan Pertanian. Surakarta : Sebelas Maret University Press.

Pertiwi, R.P. 2012. Peran Kepemimpinan Kontak Tani Dalam Proses Difusi Teknologi Pengolaan Tanaman dan Sumberdaya Terpadu Padi. Jurnal Matematika, Sains dan Teknologi 2 (1) : 51-63. 
Pribadi, N.W., \& Budoyo, G.S. 2008.

Peran ketua kelompok tani dalam menunjang keberlanjutan pengembangan usahatani konservasi di lahan kering. Jurnal Primordia 4 (3) : 229-233

Rangkuti, P.A. 2009. Analisis Peran Jaringan Komunikasi Petani dalam Adopsi Inovasi Traktor Tangan di Kabupaten Cianjur, Jawa Barat. Jurnal Agro Ekonomi 27 (1): 45-60.

Sadono, D. 2008. Pemberdayaan Petani : Paradigma Baru Penyuluhan
Pertanian di Indonesia. Jurnal Penyuluhan 4 (1) : 65-74.

Tampubolon, J., Sugihen, B.S., Slamet, M., Susanto, D., \& Sumardjo. 2006. Pemberdayaan masyarakat melalui pendekatan kelompok (Kasus pemberdayaan masyarakat miskin melalui pendekatan kelompok usaha bersama (KUBE)). Jurnal Penyuluhan 2 (2) : 10-22.

Wahyuni, S. 2003. Kinerja Kelompkok Tani dalam Sistem Usaha Tani dan Metode Pemberdayaannya. Jurnal Litbang Pertanian 22 (1) : 1-8 